\title{
Comparative analysis of nutraceutical potential of turmeric grown in different areas of Almora, Uttarakhand
}

\author{
Vasudha Agnihotri*, Smita Rana \& Sofiya Anjum
}

Center for Land and Water Resource Management, G B Pant National Institute of Himalayan Environment (Autonomous institute of MoEFCC, Govt. of India), Kosi-Katarmal, Almora, Uttarakhand.

E-mail:vasudha@gbpihed.nic.in

Received 20 October 2021; Revised 30 November 2021; Accepted 02 December 2021

\begin{abstract}
Curcuma longa (Turmeric) is an important medicinal condiment, which is known for its unique phytochemicals and biological activities. Seven turmeric powder samples obtained from five different locations of Almora District, Uttarakhand were compared for their nutraceutical potential in terms of proximate composition, phytochemical constituents such as phenolics and flavonoids, along with their antioxidant potential, curcumin, minerals etc. The commercial brand was taken for comparison purposes. Total fat was found highest in Jamradi sample $(10.07 \%)$ while lowest was found in commercial sample (2.72\%). The curcumin (5.13\%), total phenolic (2.12 mg GAE 100 $\mathrm{mg}^{-1} \mathrm{DW}$ ) and flavonoid contents (5.43 mg QE $\left.100 \mathrm{mg}^{-1} \mathrm{DW}\right)$ were highest in the Tani turmeric sample. DPPH activity of Dharad and Market samples were quite comparable (0.24 mg AAE 100 mg-1 DW), and FRAP activity was highest for Hawalbagh sample (0.44 mg AAE 100 mg-1 DW). Total fat, total moisture, phytic acid and oxalate content were identified as main factors causing difference among the turmeric samples.
\end{abstract}

Keywords: Curcuma longa, antioxidant activity, minerals, curcumin

\section{Introduction}

Curcuma longa (Turmeric), known as a golden spice belongs to Zingiberaceae family that gives many Asian dishes their yellow colour and pungent earthy flavor. It is also used as a food preservative. It is widely used in religious ceremonies, ayurvedic and folk medicines against various ailments (Tanvir et al. 2017). This herbaceous perennial is cultivated extensively in India, China, and many regions of tropical
Southeast Asia. India contributes $80 \%$ of the turmeric production in the world and Uttarakhand shares $0.18 \%$ of the total turmeric production in India (National Horticulture Board, India). As per the official website of the State Horticulture Mission, Government of Uttarakhand (2019-2020), turmeric production is 14748.65 MT from an area of 1769 ha area in the state. In Uttarakhand, Almora is the second-largest producer after Pithoragarh with a production of $313 \mathrm{MT}$ from an area of 181 ha. 
This spice is rich in proximates and other nutritional components (protein, fat, essential oil, vitamins amino acids, etc.,) and its main popular compound is curcumin which comes under curcuminoids (Serpa Guerra et al. 2020). These curcuminoids give yellowish-orange colour to the rhizome and also responsible for its therapeutic activities (Agrawal \& Goel 2016; Kumar \& Sakhya 2013; Mohebbati et al. 2017). The nutritional properties vary with locations where the plant is grown (Hossain \& Ishimine 2005; Srinivasan et al. 2016). Hence location specific studies are required which will be helpful in promoting the production of turmeric in regions where the nutritional composition and curcumin content are high. The present study is based on the analysis of the nutraceutical potential of turmeric grown in 6 different locations of Almora district of Uttarakhand in terms of their nutritional components, curcumin content, antinutrients and antioxidant potential.

\section{Materials and methods}

\section{Chemicals and reagents}

Ascorbic acid (AR), quercetin (AR), gallic acid (AR), tannic acid (AR), 1,1-diphenyl-2picrylhydrazyl (DPPH) (AR), and curcumin were procured from Sigma-Aldrich (Germany) whereas methanol (HPLC), 2,4,6-tripyridyl1,3,5-triazine (TPTZ) (AR), ferrous chloride (AR), sodium carbonate (AR), hexane $(A R)$, boric acid (AR), sulphuric acid (AR), hydrochloric acid (AR), sodium hydroxide(AR) were procured from Merck Co. (Germany).

\section{Sample collection}

Turmeric powder samples were collected from six different locations of Almora District i.e., Hawalbagh from Hawalbagh block, Tani, and Dharadfrom Bhikiyasain block, Nafda, and Pantkotll from Tarikhet block and Jamradi from Bhaisiyachhana block (FS 1), while one commercial brand sample was collected from the local market for comparison purpose.
The turmeric samples were kept in airtight well-labeled boxes at room temperature until analyzed.

\section{Extraction procedure}

$2 \mathrm{~g}$ ground turmeric samples were macerated with $30 \mathrm{ml}$ of $85 \%$ methanol at ambient conditions using rotary shaker (Remi, India) for $24 \mathrm{~h}$ and the process was repeated until the clear extract was obtained. The extracts were filtered through Whatman no. 1 filter paper, and all the extracts were mixed, stored at $-20^{\circ} \mathrm{C}$ in a freezer until further analysis.

\section{Determination of proximate parameters and curcumin content}

The nitrogen content in the turmeric samples was determined using an automated Kjeldahl apparatus (Pelican Equipments), through which the total protein content was calculated using multiplication factor 6.25. The ash content, total moisture content, and fat were determined following AOAC, 2016 method (methods $930.15 \quad$ (4.1.06); $942.05 \quad$ (4.1.10) and 2003.06 (4.5.06) methods) (George \& Latimer 2016). Total carbohydrate content was determined using the Difference Method (Kandyliari et al. 2020; Standal 1963) following equation (1)

$\%$ Carbohydrate $=100-(\%$ Moisture $\%$ Crude protein $+\%$ Total ash $+\%$ Crude fat)

\section{Estimation of total phenolics, flavonoids and curcumin content}

Total flavonoid content in the methanolic extracts was determined following modified method (Bao et al. 2005; Zhishen et al. 1999). $0.5 \mathrm{~mL}$ methanolic extracts were diluted to 2 $\mathrm{mL}$ using distilled water. Thereafter, $0.15 \mathrm{~mL}$ $5 \%$ sodium nitrite solution was added and allowed to stand for $5 \mathrm{~min}$. Further, $0.15 \mathrm{~mL}$ of $10 \%$ aluminum chloride was added in the mixture and was shaken. After 6 minutes, $1 \mathrm{~mL}$ $1 \mathrm{M}$ sodium hydroxide solution was added in the mixture, and again shaken. The mixture 
was further incubated for $15 \mathrm{~min}$ and for the measurement of total flavonoid content, the absorbance of the mixture was read at 510 $\mathrm{nm}$. The calibration curve was prepared using quercetin standard solution (1-10 $\left.\mathrm{mgL}^{-1}\right)$, which was used for the quantification of total flavonoid content in the samples. The results were expressed in mg quercetin equivalent per g dry weight of sample (mg QE $\left.100 \mathrm{mg}^{-1} \mathrm{DW}\right)$.

Total phenolic contents in the methanolic extracts were determined colorimetrically using Folin-Ciocalteu's method (Singleton \& Rossi 1965). $0.25 \mathrm{~mL}$ methanolic extract was diluted to $2 \mathrm{~mL}$ using distilled water and $0.25 \mathrm{~mL}$ Folin-Ciocalteu's reagent was added. The mixture was allowed to stand for $5 \mathrm{~min}$, further after neutralizing the mixture using sodium carbonate $(7 \%)$, the mixture was kept in the dark at ambient conditions for $90 \mathrm{~min}$. The ambience of the blue colour developed in the mixture was measured at $765 \mathrm{~nm}$ using a UV-Vis spectrophotometer. The calibration curve was prepared using gallic acid standard solutions (1-10 $\left.\mathrm{mgL}^{-1}\right)$ and was used for the quantification of total phenolic content in the samples. The results were presented in $\mathrm{mg}$ gallic acid equivalent per gram dry weight of the sample (mg GAE $100 \mathrm{mg}^{-1} \mathrm{DW}$ ).

The curcumin content (\%) in aqueous methanolic extracts (85\%) was determined using a UV-Vis spectrophotometer (Shimadzu) by measuring the absorbance at $428 \mathrm{~nm}$. The standard curve was prepared using curcumin standard ranging from $1-5 \mathrm{mg} / \mathrm{L}$ which was prepared using $85 \%$ methanol.

\section{Determination of antioxidant activity}

DPPH radical scavenging ability assay

DPPH free radical scavenging activity was performed through the modified method, originally given by Blois (Agnihotri et al. 2015; Blois 1958). $2.5 \mathrm{~mL}$ of methanolic extract was taken in test tubes and mixed with $2.5 \mathrm{~mL}$ of $0.3 \mathrm{mM}$ DPPH. The mixing was followed by incubation for $20 \mathrm{~min}$ at ambient conditions.
The absorbance of the mixture was measured at $517 \mathrm{~nm}$. Result was expressed as mg ascorbic acid equivalent per $100 \mathrm{mg}$ dry weight of the sample (mg AAE $100 \mathrm{mg}^{-1} \mathrm{DW}$ ) based on standard curve, prepared using ascorbic acid dissolved in $85 \%$ methanol with the concentration ranging from 1-10 $\mathrm{mg} \mathrm{L}^{-1}$.

\section{FRAP antioxidant assay}

Ferric reducing antioxidant power (FRAP) of the methanolic extract of turmeric samples was measured following the method given by Benzie and Strain (Benzie \& Strain 1996) with slight modifications. For the preparation of FRAP reagent, 10 volumes of $0.3 \mathrm{M}$ acetate buffer, 1 volume of $20 \mathrm{mM}$ ferric chloride, and 1 volume of $10 \mathrm{mM}$ TPTZ in $40 \mathrm{mM} \mathrm{HCl}$ were mixed. The $3.6 \mathrm{~mL}$ of FRAP reagent was added to $1.0 \mathrm{~mL}$ methanolic extract and incubated at $37^{\circ} \mathrm{C}$ for $10 \mathrm{~min}$ followed by measurement of absorbance at $593 \mathrm{~nm}$. FRAP was analyzed in terms of $\mathrm{mg}$ ascorbic acid equivalent per 100 mg dry weight of the sample (mg AAE 100 $\mathrm{mg}^{-1}$ DW) based on the calibration curve, prepared with ascorbic acid dissolved in 85\% methanol with the concentration ranging from $1-25 \mathrm{mg}$ $\mathrm{L}^{-1}$.

Determination of minerals and antinutrient content

Mineral estimation in all the turmeric samples were carried out after digesting the samples using Allen's method (Allen 1989). Sodium and potassium were analyzed using flame photometer (Systronic flame photometer 128), and phosphorus and iron were determined colorimetrically using UV-Vis spectrophotometer (George \& Latimer 2016; Murphy \& Riley 1962). Antinutrients such as tannins, phytic acid, and oxalate content were determined using standard methods (Abaza et al. 1968; Price et al. 1978; Sadasivam \& Manickam 1996; Wheeler \& Ferrel 1971). The quantification of tannin content was done based on the calibration curve of catechin standard solution (500-1000 $\mathrm{mg} \mathrm{L}^{-1}$ ), prepared in $85 \%$ methanol, and was expressed as $\mathrm{mg}$ catechin 
equivalent per $100 \mathrm{mg}$ dry weight of the sample (mg CE $100 \mathrm{mg}^{-1} \mathrm{DW}$ ). The phytic acid was quantified using ferric nitrate as standard (500$1000 \mathrm{mg} \mathrm{L}^{-1}$ ) and the analysis was carried out at $480 \mathrm{~nm}$. The results were presented in terms of phytate P mg $100 \mathrm{mg}^{-1} \mathrm{DW}$ of the sample. The oxalate was analyzed using the titrimetric method. As iron is an important mineral for the human body, and phytic acid affects its availability, so for ensuring their availability while consuming turmeric, the molar ratio of phytate to iron (Phy: Fe) was calculated using Equation (2):

$$
\text { Molar ratio }=\frac{(\text { Moles of phytate) }}{\text { (Moles of iron) }}
$$

\section{Statistical analysis}

All results in this study are reported as means of three replicate analyses. Statistical analysis of the data was done using MS Excel and SPSS 16.0. One-way analysis of variance (ANOVA) was carried out to compare the mean values of proximate nutrients, polyphenolic compounds, antioxidant potential, antinutritional factors, and mineral content among different turmeric samples using SPSS 16.0 at $\mathrm{p} \leq 0.05$. For understanding the factors responsible for the variability, turmeric samples were analyzed through factor and cluster analysis (FA and CA) using SPSS 16. Log transformation and z-score were calculated for minimizing the effect of different variables and then the factor scores were obtained using Varimax rotation method with Kaiser's normalization. A scree plot was used to identify the numbers of factors based on eigen values $(>1)$. For cluster analysis, Ward's method was used for linkage study and Euclidian distances as a measure of similarity. The proximity among the turmeric samples is presented in the form of dendrogram.

\section{Results and discussion}

Proximate parameters and mineral content

The proximate content of different turmeric samples are shown in Table 1. The proximate composition data of turmeric was compared with that of recommended values of USDA. The highest moisture content was found in the turmeric of Jamradi village (17.36\%), whereas the lowest was found in the commercial sample $(11.19 \%)$. The lower the moisture content, the longer will be the shelf life of turmeric as bacterial and mold growth is inhibited due to lower moisture availability (Bourdoux et al. 2016). Ash content represents the presence of mineral constituents in the samples, and it varied in the turmeric samples collected from different areas. The highest ash content was observed in the samples collected from Dharad region (14.07\%), while lowest was in commercial sample (6.93\%). The value of ash content was higher than the USDA recommended value except commercial sample and the sample collected from Tani area. Total carbohydrate content varied from $77.37 \%$ for commercial sample to $60.62 \%$ in the sample collected from Jamradi area, which is close to the values recommended by USDA i.e. $67.1 \%$. Among all the samples, protein content was highest in Nafda sample (2.24\%) while the lowest was recorded in Pantkotll $(0.67 \%)$, but it was much less than the USDA recommended value $(9.68 \%)$. The variation in the amount of protein content might be due to the geographical distribution or soil fertility status (presence of low nitrogen-containing soils) (Baltensperger et al. 2008). Total fat was found highest in Jamradi (10.07\%) while lowest was in commercial sample $(2.72 \%)$. The USDA recommended value for total fat is $3.25 \%$. The results of collected samples are quite comparable as reported by Chempakam \& Parthasarathy (2008), where the reported standard value of fat, carbohydrates and moisture content for turmeric were $5.1 \%, 69.4 \%$ and $13.1 \%$ respectively.

Sodium, potassium, phosphorus, nitrogen and iron contents were analyzed in turmeric samples (Table 2). Among all the analyzed minerals, potassium is the most abundant ranging from 
Table 1. Proximate composition (\%) in different turmeric samples

\begin{tabular}{ccccccc}
\hline Sample & $\begin{array}{c}\text { Protein } \\
(\%) \pm S E\end{array}$ & $\begin{array}{c}\text { Carbohydrate } \\
(\%) \pm S E\end{array}$ & $\begin{array}{c}\text { Total fat } \\
(\%) \pm S E\end{array}$ & $\begin{array}{c}\text { Moisture } \\
(\%) \pm S E\end{array}$ & $\begin{array}{c}\text { Ash } \\
(\%) \pm S E\end{array}$ & $\begin{array}{c}\text { Curcumin content } \\
(\%) \pm S E\end{array}$ \\
\hline HB & $1.89 \pm 0.16^{\mathrm{a}, \mathrm{b}}$ & $71.78 \pm 0.39^{\mathrm{b}}$ & $5.28 \pm 0.101^{\mathrm{e}}$ & $12.12 \pm 0.47^{\mathrm{b}, \mathrm{c}}$ & $8.92 \pm 0.03^{\mathrm{b}, \mathrm{c}}$ & $4.35 \pm 0.05^{\mathrm{b}}$ \\
NF & $2.24 \pm 0.06^{\mathrm{a}}$ & $67.55 \pm 0.28^{\mathrm{c}}$ & $7.11 \pm 0.04^{\mathrm{c}}$ & $14.94 \pm 0.22^{\mathrm{c}, \mathrm{d}}$ & $8.14 \pm 0.04^{\mathrm{c}, \mathrm{d}}$ & $4.31 \pm 0.02^{\mathrm{b}}$ \\
TA & $1.72 \pm 0.04^{\mathrm{a}, \mathrm{b}}$ & $65.31 \pm 0.30^{\mathrm{d}}$ & $9.52 \pm 0.08^{\mathrm{b}}$ & $16.47 \pm 0.26^{\mathrm{d}, \mathrm{e}}$ & $6.96 \pm 0.16^{\mathrm{d}, \mathrm{e}}$ & $5.13 \pm 0.11^{\mathrm{a}}$ \\
PT & $0.67 \pm 0.04^{\mathrm{c}}$ & $68.99 \pm 0.22^{\mathrm{c}}$ & $6.24 \pm 0.13^{\mathrm{d}}$ & $14.77 \pm 0.15^{\mathrm{b}, \mathrm{c}}$ & $9.32 \pm 0.24^{\mathrm{b}, \mathrm{c}}$ & $2.70 \pm 0.01^{\mathrm{d}}$ \\
JM & $1.99 \pm 0.22^{\mathrm{a}, \mathrm{b}}$ & $60.62 \pm 0.19^{\mathrm{e}}$ & $10.07 \pm 0.089^{\mathrm{a}}$ & $17.36 \pm 0.25^{\mathrm{a}}$ & $9.95 \pm 0.16^{\mathrm{b}}$ & $4.31 \pm 0.03^{\mathrm{b}}$ \\
DH & $1.57 \pm 0.04^{\mathrm{b}}$ & $59.58 \pm 0.56^{\mathrm{e}}$ & $9.92 \pm 0.028^{\mathrm{a}}$ & $14.84 \pm 0.12^{\mathrm{b}}$ & $14.07 \pm 0.49^{\mathrm{a}}$ & $3.31 \pm 0.05^{\mathrm{c}}$ \\
MT & $1.78 \pm 0.01^{\mathrm{a}, \mathrm{b}}$ & $77.37 \pm 0.17^{\mathrm{a}}$ & $2.72 \pm 0.06^{\mathrm{f}}$ & $11.19 \pm 0.13^{\mathrm{e}}$ & $6.93 \pm 0.24^{\mathrm{e}}$ & $3.22 \pm 0.01^{\mathrm{c}}$ \\
\hline
\end{tabular}

Hawalbagh (HB), Nafda (NF), Tani (TA), Pantkotll (PT), Jamradi (JM), Dharad (DH), Market (MT). Means with different alphabets within the same column indicate significant difference between samples on Post Hoc tukey test $(\mathrm{P} \leq 0.05)$.

$1140.55\left(\mathrm{mg} 100 \mathrm{~g}^{-1}\right)$ in Tani sample to 1482.77 $\left(\mathrm{mg} 100 \mathrm{~g}^{-1}\right)$ in Dharad sample. Sodium content was found to vary between $18.72\left(\mathrm{mg}^{\left.100 \mathrm{~g}^{-1}\right)}\right.$ for Hawalbagh sample to $61.11\left(\mathrm{mg} 100 \mathrm{~g}^{-1}\right)$ for Pantkotll sample. Iron content varied between $37.47\left(\mathrm{mg} 100 \mathrm{~g} \mathrm{~g}^{-1}\right)$ for Nafda sample to 86.8 (mg $100 \mathrm{~g}^{-1}$ ) for Hawalbagh sample. Phosphorus content ranged from $258.48\left(\mathrm{mg} 100 \mathrm{~g} \mathrm{~g}^{-1}\right)$ for
Pantkotll sample to 447.37 (mg $100 \mathrm{~g}^{-1}$ ) for Hawalbagh sample. The mineral content in the plant produce depending upon the soil where it is grown. Varying content of N, P, K and Fe in turmeric samples were reported by various researchers (Balakrishnan 2007, Bamigboye et al. 2020, Ahamefula et al. 2014, Taoheed et al. 2017)

Table 2. Mineral content (mg $100 \mathrm{~g}^{-1}$ ) in different turmeric samples

\begin{tabular}{|c|c|c|c|c|}
\hline Sample & $\mathrm{Na}\left(\mathrm{mg} 100 \mathrm{~g}^{-1}\right) \pm \mathrm{SE}$ & $\mathrm{K}\left(\mathrm{mg} 100 \mathrm{~g}^{-1}\right) \pm \mathrm{SE}$ & $\mathrm{Fe}\left(\mathrm{mg} 100 \mathrm{~g}^{-1}\right) \pm \mathrm{SE}$ & $\mathrm{P}\left(\mathrm{mg} 100 \mathrm{~g}^{-1}\right) \pm \mathrm{SE}$ \\
\hline $\mathrm{HB}$ & $18.72 \pm 1.25^{c}$ & $1363.889 \pm 10.09^{\mathrm{b}}$ & $86.8 \pm 2.00^{\mathrm{a}}$ & $447.37 \pm 6.70^{\mathrm{a}}$ \\
\hline NF & $57.44 \pm 2.31^{\mathrm{a}}$ & $1281.722 \pm 15.39^{\mathrm{b}, \mathrm{c}}$ & $37.47 \pm 1.76^{c}$ & $320.6 \pm 3.47^{b}$ \\
\hline TA & $19.83 \pm 0.34^{\mathrm{c}}$ & $1140.556 \pm 12.01^{\mathrm{d}}$ & $41.47 \pm 2.90^{\mathrm{b}, \mathrm{c}}$ & $287.27 \pm 8.02^{\mathrm{d}, \mathrm{e}}$ \\
\hline PT & $61.11 \pm 2.96^{\mathrm{a}}$ & $1252.222 \pm 19.10^{c}$ & $56.8 \pm 1.15^{\mathrm{b}}$ & $258.48 \pm 4.44^{\mathrm{f}}$ \\
\hline $\mathrm{JM}$ & $36 \pm 9.43^{b, c}$ & $1249.556 \pm 10.36^{c}$ & $48.8 \pm 2.31^{\mathrm{b}, \mathrm{c}}$ & $261.01 \pm 7.95^{\mathrm{e}, \mathrm{f}}$ \\
\hline $\mathrm{DH}$ & $43.90 \pm 2.13^{\mathrm{a}, \mathrm{b}}$ & $1482.778 \pm 10.21^{\mathrm{a}}$ & $42.8 \pm 5.78^{\mathrm{b}, \mathrm{c}}$ & $318.83 \pm 2.16^{\mathrm{b}, \mathrm{c}}$ \\
\hline MT & $35.166 \pm 0.57^{b, c}$ & $1123.944 \pm 9.71^{\mathrm{d}}$ & $44.8 \pm 6.93^{\mathrm{b}, \mathrm{c}}$ & $291.06 \pm 4.93^{c, d}$ \\
\hline
\end{tabular}

Hawalbagh (HB), Nafda (NF), Tani (TA), Pantkotll (PT), Jamradi (JM), Dharad (DH), Market (MT). Sodium (Na), potassium $(\mathrm{K})$, iron $(\mathrm{Fe})$, phosphorus $(\mathrm{P})$. Means with different alphabets within the same column indicate significant difference between samples on Post Hoc tukey test $(\mathrm{P} \leq 0.05)$. 
Total flavonoid, phenolic, curcumin, and antinutrient contents

Flavonoids are considered as plant pigments which are responsible for the colour of plants and help in their health-promoting activities through their high pharmacological potential as radical scavengers (Cook \& Samman 1996). In our study, total flavonoid content was reported to be highest in methanolic extract of Tani sample i.e. $5.43 \mathrm{mg}$ QE $100 \mathrm{mg}^{-1} \mathrm{DW}$ and lowest in methanolic extract of Hawalbagh sample i.e. $3.315 \mathrm{mg}$ QE $100 \mathrm{mg}^{-1} \mathrm{DW}$ (Figure $1)$. These results fall in the similar range as reported (Sumazian et al. (2010) and Tilak et al. (2004). Plant based phenolics are important constituents that contribute to color, functional quality, flavor and play important roles both as singlet oxygen quenchers and free radical scavengers, that helps to minimize molecular damage (Tanvir et al. 2015). In our study, total phenolic content was reported to be highest in Tani sample (2.12 mg GAE $100 \mathrm{mg}^{-1}$ DW) and lowest in Hawalbagh sample 1.35 mg GAE $100 \mathrm{mg}^{-1}$ DW (Figure 1).Curcumin is an exceptionally important polyphenol which has anti-inflammatory and anti-cancer characteristics and has been utilized in several medical preparations for ages. Among the turmeric samples curcumin content was highest in Tani sample (5.13\%) and lowest in the Pantkotll $(2.70 \%)$. Such variation might be due to the genetic variability of turmeric cultivars, from which final turmeric powder was prepared (Anandaraj et al. 2014). Similar results was observed in the turmeric cultivars grown in Himachal Pradesh which was ranging from 3.61-5.19\% (Choudhary \& Rahi 2018).

The antinutrients such as phytic acid, tannicacid and oxalic acid were analyzed in the turmeric samples. Tannic acid was found to vary from $17.58 \%$ in Dharad sample to $21.30 \%$ in Tani sample, whereas phytic acid was found in the

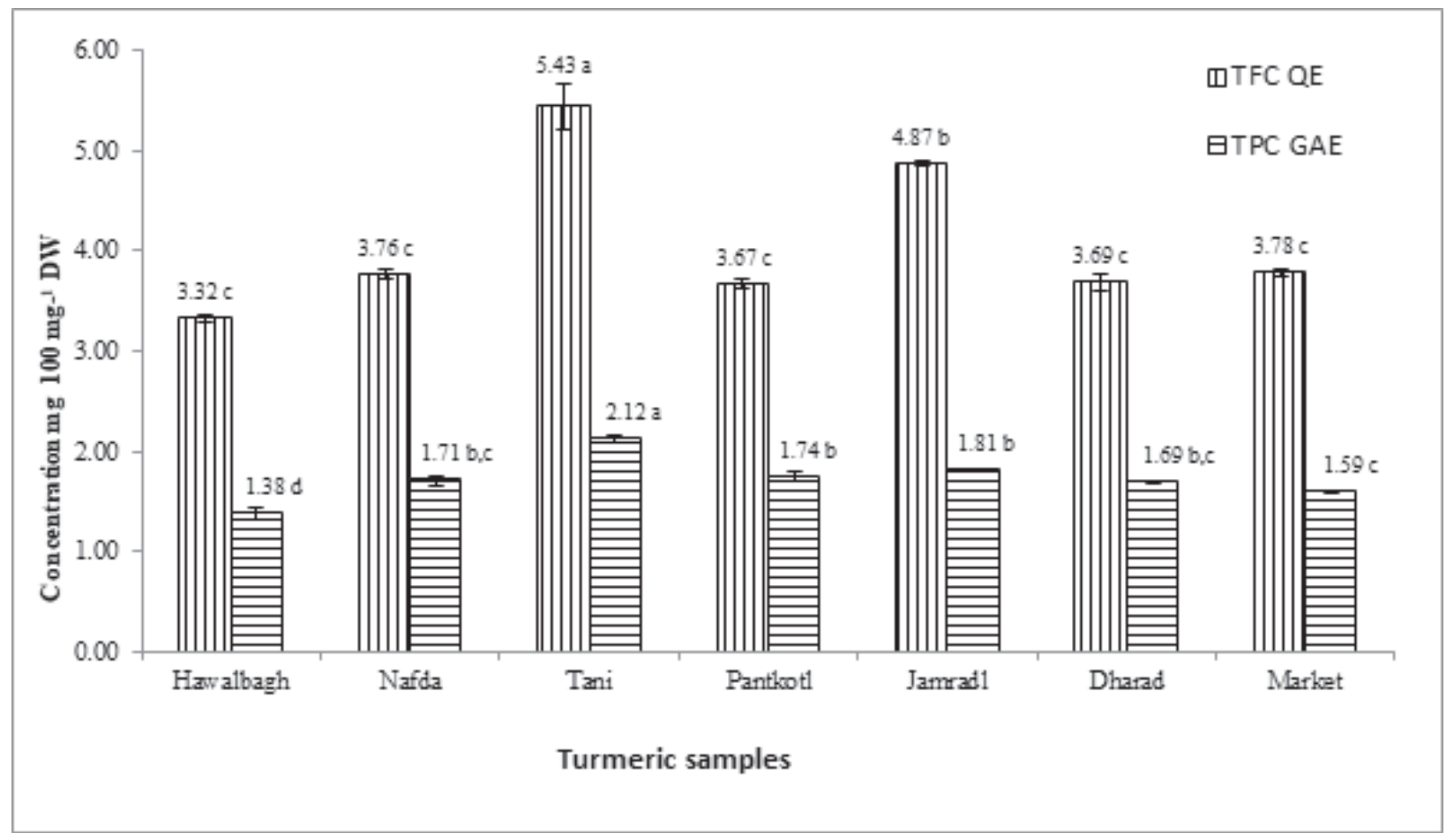

Fig. 1 Total flavonoid and phenolic content in the turmeric samples

Data points marked above the bar are the concentration of total phenolic content (mg GAE $100 \mathrm{mg}^{-1} \mathrm{DW}$ ) and total flavanoid content (mg quercitine $100 \mathrm{mg}^{-1} \mathrm{DW}$ ). Values with different alphabets within the same column indicate significant difference between samples on Post Hoc tukey test $(\mathrm{P} \leq 0.05)$ 


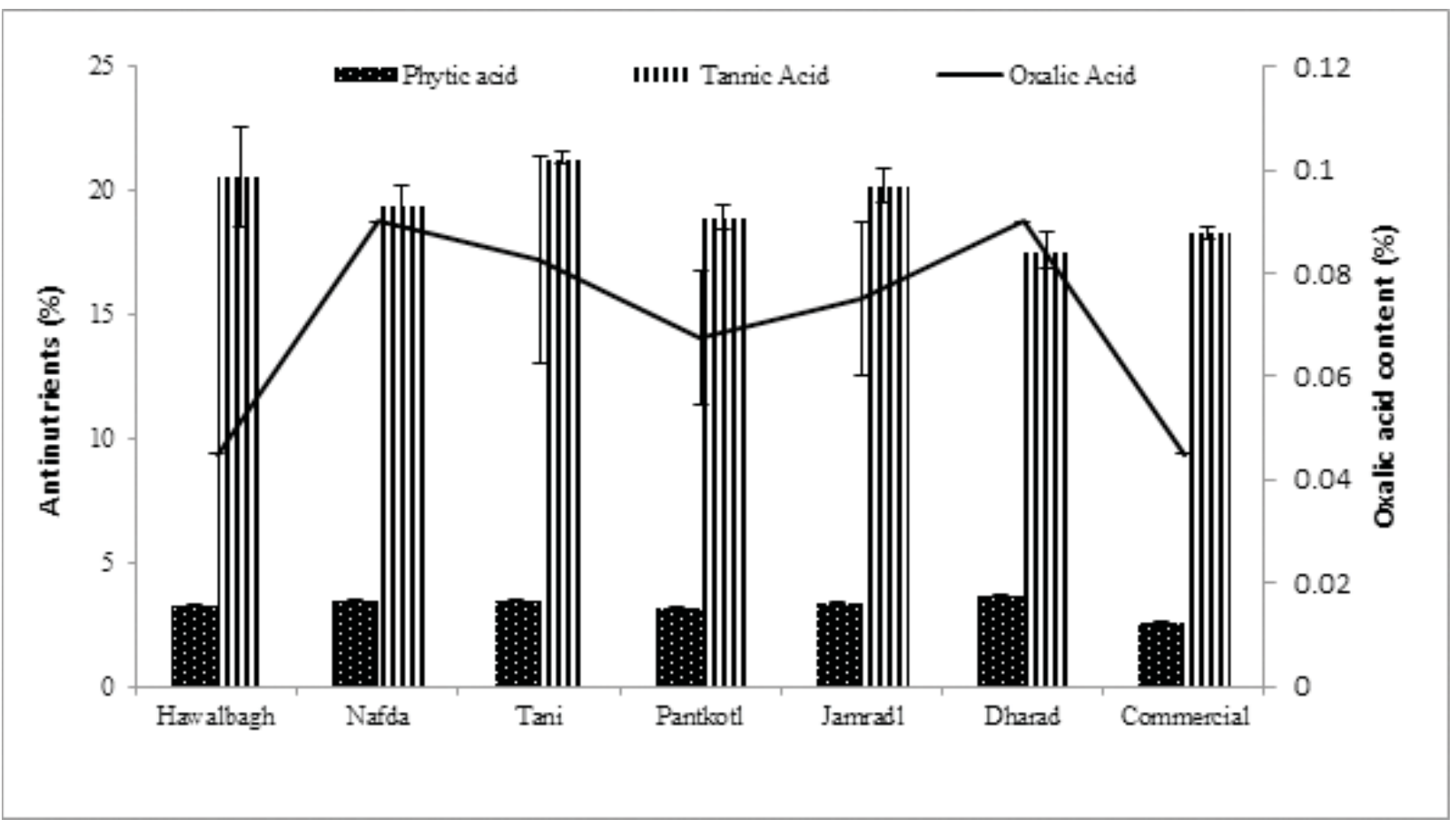

Fig. 2 Antinutrients content in the turmeric samples

range of $2.60 \%$ in commercial sample to $3.66 \%$. in Dharad sample and oxalate from $0.045 \%$ in commercial sample to $0.90 \%$ in Nafda sample (Figure 2). Plants can accumulate significant concentrations of antinutritional components, which can interfere in the digestibility and bioavailability of nutrients in the human body (Braga et al. 2018). Phytate plays an important role in lowering the bioavailability of multivalent cations such as $\mathrm{Ca}^{2+}, \mathrm{Mg}^{2+}, \mathrm{Zn}^{2+}$, $\mathrm{Fe}^{2+}$, and $\mathrm{Fe}^{3+}$ by establishing insoluble metal complexes and rendering them unavailable to humans and animals (Reddy \& Salunkhe 1980). However, phytate : iron ratio of $>1$ as observed in the present study indicate that the iron present in the turmeric will be absorbed in the body without getting affected by the presence of phytic acid (Agnihotri et al. 2020; Hallberg et al.1989).

\section{Antioxidant activity}

Turmeric has significant 1,1-diphenyl-2 -picrylhydrazyl (DPPH), superoxide anion radical scavenging, and metal-chelating, ferric reducing/antioxidant power (FRAP) activity (Zhao et al. 2010) due to the presence of natural phenolic compounds such as curcuminoids. Among the samples, DPPH activity of Dharad and Market samples was quite comparable (0.24 mg AAE $\left.100 \mathrm{mg}^{-1} \mathrm{DW}\right)$, while the lowest activity was found in the Tani sample (0.112 mg AAE $100 \mathrm{mg}^{-1} \mathrm{DW}$ ) (Figure 3). The FRAP activity was the lowest for Jamradi sample

Table 3. Phytic acid and iron ratio in different turmeric samples

\begin{tabular}{cc}
\hline Sample & PA/Iron \pm SE \\
\hline HB & $3.20 \pm 0.07$ \\
NF & $7.84 \pm 0.33$ \\
TA & $7.12 \pm 0.48$ \\
PT & $4.70 \pm 0.11$ \\
JM & $5.86 \pm 0.29$ \\
DH & $7.51 \pm 1.00$ \\
MT & $5.19 \pm 0.93$ \\
\hline
\end{tabular}

Hawalbagh (HB), Nafda (NF), Tani (TA), Pantkotll (PT), Jamradl (JM), Dharad (DH), Market (MT) 


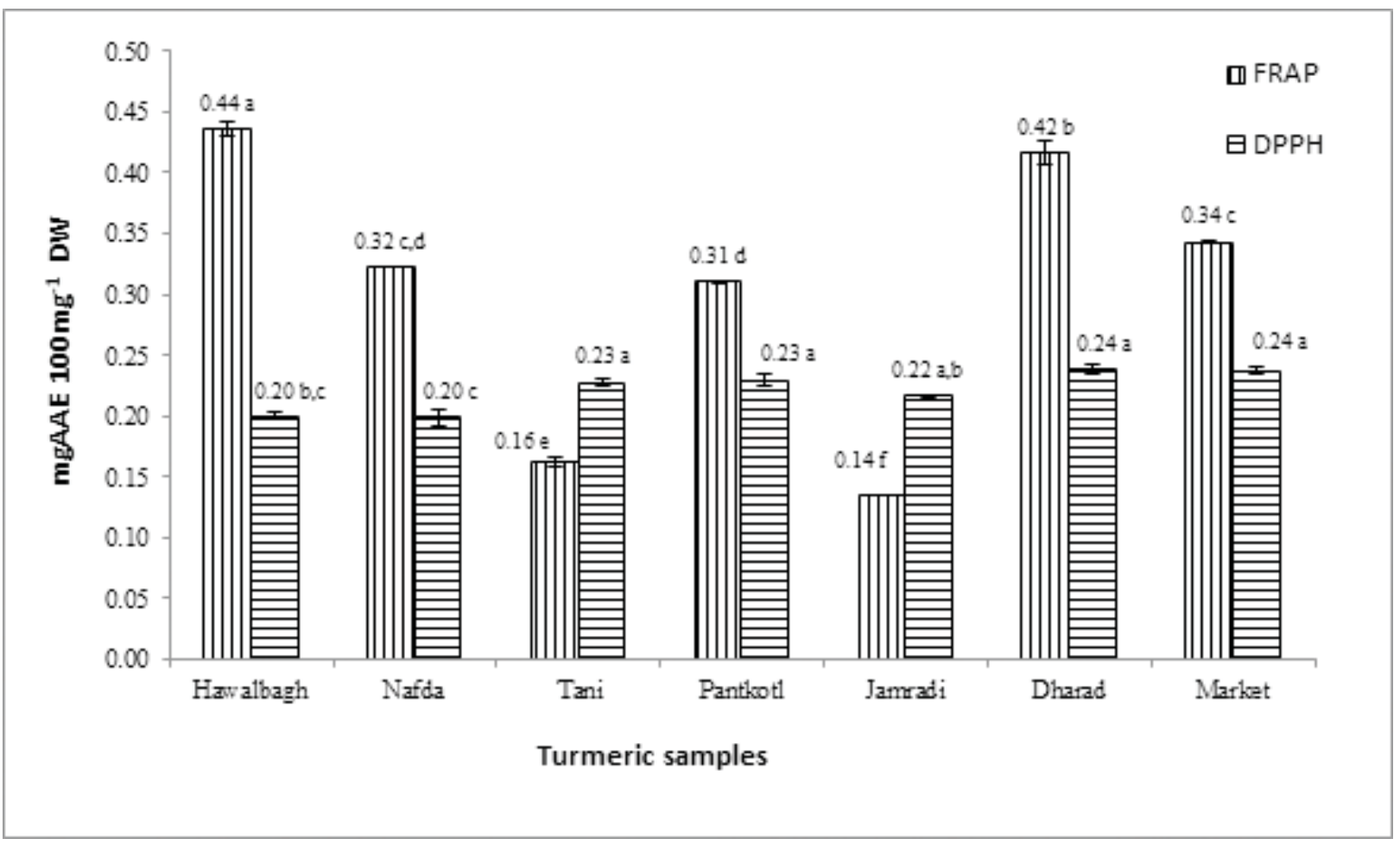

Fig. 3 Antioxidant activity of the turmeric samples in terms of FRAP and DPPH.

Data points marked above the bar are the concentration (mg AAE $100 \mathrm{mg}^{-1} \mathrm{DW}$ ) for DPPH and FRAP. Values with different alphabets within the same column indicate significant difference between samples on Post Hoc tukey test $(\mathrm{P} \leq 0.05)$

(0.14 mg AAE $100 \mathrm{mg}^{-1} \mathrm{DW}$ ) while the highest activity was recorded in Hawalbagh sample (0.44 mg AAE $\left.100 \mathrm{mg}^{-1} \mathrm{DW}\right)$. Correlation analysis was conducted between total phenolic and flavonoid contents and antioxidant activity and it was observed that phenolic and flavonoid content are not linearly correlated $(\mathrm{p} \leq 0.05)$. It ispossible that there might be some other bioactive compounds which might be responsible for the antioxidant activity of these samples. The similar conclusion was also drawn earlier by Supawadee Burapan et al. (2020).

\section{Multivariate analysis}

For analyzing the differences among the selected turmeric samples, factor and cluster analysis were conducted and the results are shown in Table 4 and Figure 4 . Four factors were obtained with the total variance of $79.38 \%$ among all the analyzed parameters for the targeted turmeric samples. The factor 1 was responsible for $33.54 \%$ of total variance and showed high positive loading $(>0.70)$ for total fat, total moisture, phytic acid and oxalate which shows that these parameters are strongly affecting the variation among the targeted turmeric samples and negative loading for total carbohydrates. Factor 2 is accounting for $18.96 \%$ of total variance with positive loading for FRAP activity, iron and phosphorus whereas negative loading for total phenolic content. This depicts that total phenolic content is not responsible for FRAP activity. Factor 3 accounts for $19.25 \%$ of total variance with positive loading for total flavonoids, curcumin content, and antinutrient tannic acid. Factor 4 accounts for $7.63 \%$ of total variance with the positive loading for total protein. The analysis shows that total fat, phytic acid and oxalic acid are the main variables which are the cause of variation among the turmeric samples. 
Table 4. Factor analysis for analyzing the parameters responsible for the variation of nutraceutical potential of turmeric samples

\begin{tabular}{lcccc}
\hline Parameter & PC1 & PC2 & PC3 & PC4 \\
\hline Total protein & 0.045 & 0.166 & -0.01 & 0.955 \\
Total carbohydrate & -0.951 & -0.045 & 0.129 & 0.019 \\
Total Fat & 0.967 & 0.238 & -0.083 & -0.035 \\
Total Moisture & 0.804 & 0.412 & -0.356 & -0.186 \\
Total ash & 0.692 & -0.57 & 0.236 & -0.163 \\
Total Phenolic content & 0.445 & 0.035 & -0.765 & -0.157 \\
Total flavonoid content & 0.456 & 0.855 & -0.001 & 0.137 \\
DPPH & -0.547 & -0.631 & 0.047 & 0.477 \\
FRAP & 0.204 & -0.03 & 0.917 & -0.004 \\
Curcumin & 0.001 & 0.854 & -0.314 & -0.109 \\
Tannic acid & 0.09 & 0.884 & 0.275 & 0.149 \\
Phytic acid & 0.958 & 0.026 & 0.085 & 0.135 \\
Oxalic acid & 0.815 & -0.012 & -0.556 & 0.019 \\
Sodium & 0.121 & -0.616 & -0.566 & -0.388 \\
Potassium & 0.62 & -0.63 & 0.46 & 0.081 \\
Iron & -0.192 & 0.04 & 0.941 & -0.226 \\
Phosphorus & -0.067 & -0.212 & 0.755 & 0.535 \\
Eigen value & 6.426 & 3.97 & 3.718 & 1.58 \\
Total variance (\%) & 33.54 & 18.96 & 19.25 & 7.63 \\
Cumulative variance (\%) & 33.54 & 52.50 & 71.75 & 79.38 \\
\hline
\end{tabular}

Dendrogram using Ward Method

Rescaled Distance Cluster Combine

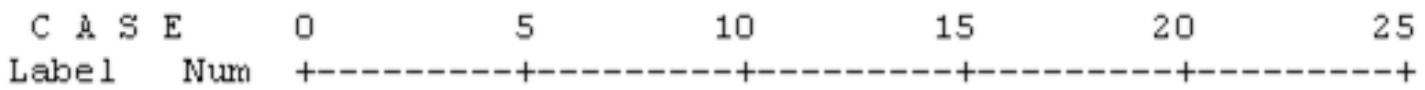

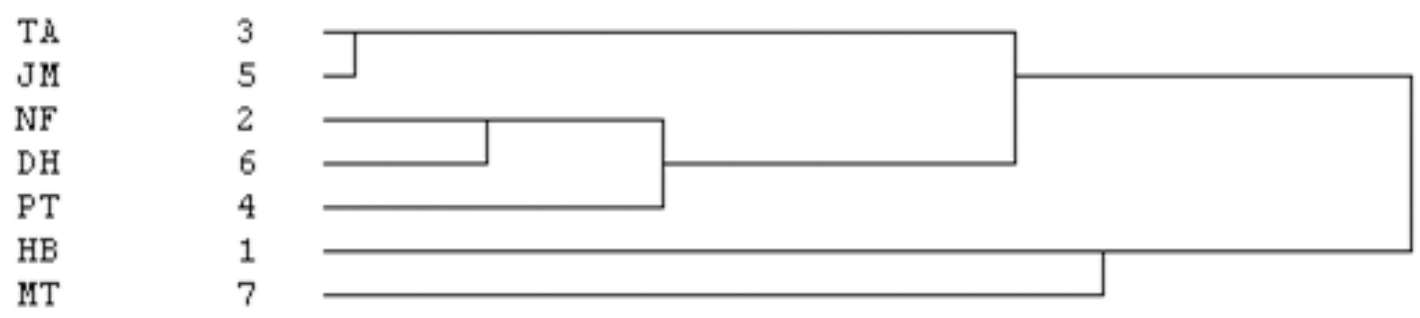

Fig. 4 Clustering of turmeric samples based on the targeted parameters 
Through cluster analysis, it was observed that all the targeted turmeric samples could be categorized into two main clusters (Figure 4). In the cluster 1 (C1), Hawalbagh sample and market sample were clustered while rest of the samples were grouped another cluster (C2). Similarity between Hawalbagh sample and market sample is well justified as reviewed by chemical characteristics of both the samples. C2 is further grouped into two sub-clusters, where the turmeric samples of Tani and Jamradi region were grouped in separate sub-cluster (SC1), whereas turmeric samples of Nafda, Dharad and Pantkotll region were grouped in another sub-cluster (SC2). In SC2, Nafda and Dharad samples are in proximity. The differences in nutritional parameters and the respective clustering might be due to the variability in the climatic and soil conditions. Arya et al. (2019) reported the soil characteristics of different block of Almora districts show that the soil of areas where turmeric were cultivated was loamy sand to silty clay loam/ sandy loam to silty clay loam and the micro and macro nutrient contents were also varying in these areas (Arya et al. 2019). Hawalbagh block was low in nitrogen $(\mathrm{N})$, sulfur $(\mathrm{S})$ and boron (B), medium in copper $(\mathrm{Cu})$, and high in rest of the other nutrients, Tarikhet block was low in $\mathrm{N}$, medium in $B$ and high in rest. Bhikiyasain block was low in $\mathrm{N}$, medium in Fe and $\mathrm{B}$, high in rest. Bhaisiyachhana block was low in $\mathrm{N}$, medium in $\mathrm{B}$ and high in rest nutrients. This variation in soil nutrient conditions might be responsible for the variability of nutritional contents along with the genetic variability.

\section{Conclusion}

The turmeric is used both as spices as well as in different types of phytomedicines due to its several health benefits. As the turmeric is valued mainly for its curcumin along with many other phytochemicals and minerals, in terms of curcumin, turmeric sample from Tani (TA) village was found best followed by Hawalbagh (HB), Nafda (NF), Jamradl (JM). Total phenolic and flavonoids content were also highest in Tani turmeric sample. Turmeric is also important for its antioxidant activity which was found highest for Hawalbagh turmeric sample followed by that of Dharad in terms of FRAP and in terms of DPPH activity, it was highest and equivalent in the turmeric samples fromTani (TA), Jamradi (JM), Dharad(DH), Market (MT).

\section{Acknowledgements}

Authors are grateful to Director GBP-NIHE for extending the facilities and Department of Science and Technology- Natural Resource Data Management System (DST-NRDMS) for financial support. Shri Manuj Goyal as Chief Development Officer, Almora is duly acknowledged for arrangement of turmeric samples from the selected places.

\section{References}

Abaza R H, Blake J T \& Fisher E J 1968 Oxalate determination: analytical problems encountered with certain plant species. J. AOAC Int. 51: 963-967.

Agnihotri V, Anjum S \& Rana S 2020 Nutraceutical potential of North-West Himalayan spices Allium stracheyi and Angelica glauca and their comparison with commonly used spices. J. Food Meas. Charact. 1-12.

Agnihotri V, Sati P, Jantwal A \& Pandey A 2015 Antimicrobial and antioxidant phytochemicals in leaf extracts of Bergenia ligulata: a Himalayan herb of medicinal value. Nat. Prod. Res. 29(11): 1074-1077.

Agrawal S \& Goel R K 2016 Curcumin and its protective and therapeutic uses. Natl. J. Physiol. Pharm. Pharmacol. 6(1): 1-8.

Ahamefula I, Onwuka G I \& Chibuzo N 2014 Nutritional composition of tumeric (Curcuma longa) and its antimicrobial properties. Int. J. Sci. Eng. Res. 5(10): 1085-1089.

Allen S E 1989 Chemical Analysis of Ecological Materials. Oxford: Blackwell Scientific Publications. 2nd ed.

Anandaraj M, Prasath D, Kandiannan K, Zachariah T J, Srinivasan V et al. 2014 Genotype by environment interaction effects on yield and 
curcumin in turmeric (Curcuma longa L.). Ind. Crops Prod. 53: 358-364.

Arya R P, Pachauri S P \& Srivastava P C 2019 Status of some macro- and micro-nutrients in soils of Almora district of Uttarakhand. Pantnagar J. Res. 17(2): 138-146.

Balakrishnan K V 2007 Postharvest technology and processing of turmeric. In Turmeric: The Genus Curcuma, ed. K P. N. Ravindran, Babu, K. Nirmal, Sivaraman, pp. 214-256. Taylor \& Francis Group, LLC.

Baltensperger D D, Cassman K G, Mason S C, Pavlista A D \& Blumenthal J M 2008 Importance and Effect of Nitrogen on Crop Quality and Health. Nitrogen Environ. 51-70.

Bamigboye A Y, Adepoju O T \& Oladipo P O 2020 Evaluation of physiochemical properties and mineral content of some indigenous spices retailed in Ibadan, Nigera. Int. J. Nutr. 6(1): 20-34.

Bao J, Cai Y, Sun M, Wang G \& Corke H 2005 Anthocyanins, flavonols and free radical scavenging activity of Chinese Bayberry (Myrica rubra) extracts and their color properties and stability. J. Agric. Food Chem. 53: 2327-2332.

Benzie I F F \& Strain J J 1996 The Ferric Reducing Ability of Plasma (FRAP) as a Measure of "'Antioxidant Power"': The FRAP Assay. Anal. Biochem. 239: 70-76.

Blois MS 1958 Antioxidant determination by the use of stable free radical, Nature, 181: 1199-2000.

Bourdoux S, Li D, Rajkovic A, Devlieghere F \& Uyttendaele M 2016 Performance of Drying Technologies to Ensure Microbial Safety of Dried Fruits and Vegetables. Compr. Rev. Food Sci. Food Saf. 15(6): 1056-1066.

Braga M C, Vieira E C S \& Oliveira T F de 2018 Curcuma longa L. leaves: Characterization (bioactive and antinutritional compounds) for use in human food in Brazil. Food Chem. $1-26$.

Chempakam B \& Parthasarathy V A 2008 Turmeric chapter.

Choudhary A K \& Rahi S 2018 Organic cultivation of high yielding turmeric (Curcuma longa
L.) cultivars: a viable alternative to enhance rhizome productivity, profitability, quality and resource-use efficiency in monkeymenace areas of north-western Himalayas. Ind. Crops Prod. 124: 495-504.

Cook N C \& Samman S 1996 Flavonoids-Chemistry, metabolism, cardioprotective effects, and dietary sources. Nutr. Biochem. 7: 66-76.

Dohare P, Garg P, Sharma U, Jagannathan N \& Madhur R 2008 Neuroprotective efficacy and therapeutic window of Curcuma oil: in rat embolic stroke model. BMC Complement. Altern. Med. 8(55): 1-20.

George J \& Latimer W 2016 Official Methods of Analysis of AOAC International. United States of America. 20th ed.

Hallberg L, Brune M \& Rossander L 1989 Iron absorption in man: ascorbic acid and dosedependent inhibition by phytate. Am. J. Clin. Nutr. 49: 140-144.

Himaja M, Ranjitha A, Ramana M V, Anand M \& Asif K 2010 Phytochemical screening and antioxidant activity of rhizome part of Curcuma zedoaria. Int. J. Res. Ayurveda Pharm.1(2): 414-417.

Hossain A \& Ishimine Y 2005 Growth, yield and quality of turmeric (Curcuma longa L.) cultivated on dark-red soil, gray soil and red soil in Okinawa, Japan. Plant Prod. Sci. 8(4): 482-486.

Kandyliari A, Mallouchos A, Papandroulakis N, Golla J P, Lam T T et al. 2020 Nutrient Composition and Fatty Acid and Protein Profiles of Selected Fish By-Products. Foods. 9(190): 1-14.

Khalandar S D, Adithya T N, Basha S J, Koshma M, Subbareddy U V \& Reddy V J S 2018 A current review on Curcuma longa Linn. plant. Int. J. Pharm. Chem. b Bological Sci. 8(1): 68-73.

Kumar N \& Sakhya S K 2013 Ethnopharmacological properties of Curcuma longa: A review. Int. J. Pharm. Sci. Res. 4(1): 103-112.

Mohebbati R, Anaeigoudari A \& Khazdair M R 2017 The effects of Curcuma longa and curcumin on reproductive systems. Endocr. Regul. 51(4): 220-228. 
Murphy J \& Riley J P 1962 A modified single solution method for the determination of phosphate in natural waters. Anal. Chim. Acta. 27: 31-36.

Price M L, Scoyoc S Van \& Butler L G 1978 A critical evaluation of the vanillin reaction as an assay for tannin in Sorghum grain. J. Agric. Food Chem. 26(5): 1214-1218.

Reddy N R \& Salunkhe D K 1980 Effects of fermentation on phytate phosphorus and mineral content in black gram, rice and black gram and rice blends. J. Food Sci. 45: 1708-12.

Sadasivam S \& Manickam A 1996 Biochemical Methods. New Delhi: New Age International Publishers. 2nd ed.

Serpa Guerra AM, Gómez Hoyos C, Velásquez-Cock J A, Vélez Acosta L, Gañán Rojo P et al. 2020. The nanotech potential of turmeric (Curcuma longa L.) in food technology: A review. Crit. Rev. Food Sci. Nutr. 60(11): 1842-1854.

Shrishail D, K H H, Ravichandra H, Tulsianand G \& Shruthi S D 2013 Turmeric: Nature's precious medicine. Asian J. Pharm. Clin. Res. 6(3): $10-16$.

Singletary K \& Eith 2010 Turmeric: An overview of potential health benefits. Nutr. Today. 45(5): 216-225.

Singleton V L \& Rossi J A 1965 Colorimetry of total phenolics with phosphomolybdicphosphotungstic acid reagents. Am. J. Enol. Vitic. 16: 144-158.

Srinivasan V, Thankamani C K, Dinesh R, Kandiannan K, Zachariah T J et al. 2016 Nutrient management systems in turmeric: Effects on soil quality, rhizome yield and quality. Ind. Crop. Prod. 85: 241-250.

Standal B R 1963 Nutritional Value of Proteins of Oriental. J. Nutr. 81: 279-285.

Sumazian Y, Syahida A, Hakiman M \& Maziah M 2010 Antioxidant activities, flavonoids, ascorbic acid and phenolic contents of Malaysian vegetables. J. Med. Plants Res. 4(10): 881-890.
Tanvir E M, Afroz R, Karim N, Mottalib M A, Hossain M I et al. 2015 Antioxidant and antibacterial activities of methanolic extract of Bau Kul (Ziziphus mauritiana), an improved variety of fruit from Bangladesh. J. Food Biochem. 1-9.

Tanvir E M, Hossen M S, Hossain M F, Afroz R, Gan S H et al. 2017 Antioxidant properties of popular turmeric (Curcuma longa) varieties from Bangladesh. J. Food Qual. 1-8.

Taoheed A A, Tolulope A A, Saidu A B, Odewumi O G, Sunday R M \& Usman M 2017 Phytochemical properties, proximate and mineral composition of Curcuma longa Linn, and Zingiber officinale Rosc .: A comparative study. J. Sci. Res. Reports. 13(4): 1-7.

Tilak J C, Banerjee M, Mohan H \& Devasagayam T P A 2004 Antioxidant availability of turmeric in relation to its medicinal and culinary uses. Phyther. Res. 18: 798-804.

Tsai S Y, Huang S J, Chyau C C, Tsai C H, Weng C C \& Mau J L 2011 Composition and antioxidant properties of essential oils from Curcuma rhizome. Asian J. Pharm. Sci. 2: 57-66.

Verma R K, Kumari P, Maurya R K, Kumar V, Verma R B \& Singh R K 2018 Medicinal properties of turmeric (Curcuma longa L): A review. Int. J. Chem. Stud. 6(4): 1354-1357.

Wheeler E \& Ferrel R E 1971 A method for Phytic Acid Determination in Wheat and Wheat Fractions. Cereal Chem. 48: 312-320.

Zhang L, Yang Z, Chen F, Su P, Chen D et al. 2017. Composition and bioactivity assessment of essential oils of Curcuma longa L. collected in China. Ind. Crops Prod. 109: 60-73.

Zhao J, Zhang J, Yang B, Lv G-P \& Li S-P 2010 Free radical scavenging activity and characterization of sesquiterpenoids in four species of Curcuma using a TLC bioautography assay and GC-MS analysis. Molecules. 15: 7547-7557.

Zhishen J, Mengcheng T \& Jianming W 1999 The determination of flavonoid contents in mulberry and their scavenging effects on superoxide radicals. 